CATALAN REVIEW

Catalan Review

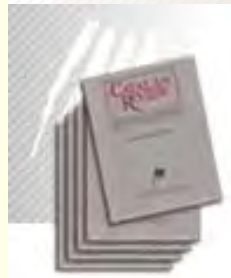

You are accessing the Digital Archive of the Catalan Review Journal.

By accessing and/or using this Digital Archive, you accept and agree to abide by the Terms and Conditions of Use available at http://www.nacs-

catalanstudies.org/catalan_review.html

Catalan Review is the premier international scholarly journal devoted to all aspects of Catalan culture. By Catalan culture is understood all manifestations of intellectual and artistic life produced in the Catalan language or in the geographical areas where Catalan is spoken. Catalan Review has been in publication since 1986 .
NORTH

AMERICAN

CATALAN

SOCIETY
Esteu accedint a l'Arxiu Digital del Catalan Review

A l' accedir i / o utilitzar aquest Arxiu Digital, vostè accepta i es compromet a complir els termes i condicions d'ús disponibles a http://www.nacs-

catalanstudies.org/catalan_review.html

Catalan Review és la primera revista internacional dedicada a tots els aspectes de la cultura catalana. Per la cultura catalana s'entén totes les manifestacions de la vida intel lectual i artística produïda en llengua catalana o en les zones geogràfiques on es parla català. Catalan Review es publica des de 1986.

\title{
J. V. Foix or Total Investigation Joaquim Molas
}

Catalan Review, Vol. I, number 1, (1986), p. 107-122 


\section{J. V. FOIX OR TOTAL INVESTIGATION}

\section{JOAQUIM MOLAS}

J. V. Foix, like Riba and Folguera, was heir to the Prat de la Riba-Eugeni D'Ors influence, and like them, shaped in the purest springs of symbolism, he participated at a certain distance, but with total conviction, in the adventure of Avantguardism. Literature is, for him, an inquiry: "the ambition of poetry is to satisfy itself as an immediate instrument of investigation". 1 Above all, a moral and metaphysical inquiry. In effect, Foix, through his poems and prose intended to describe the reality that surrounded him or, more exactly, the relationship, from the first moment, established between him and his mind and between the latter and the reality of each day. He said in an essay written in 1927 :

In art and in literature the distinction between sincerity and conviction is necessary. For that reason it is necessary, isn't it, to give an emotional context to the word sincere and an intellectual context to the word convince. Normally, sincerity affects the feelings: one is sincere when one exposes that which one has proved without dissimulation. Conviction is of the rational order: argument and proof, dialectic and logic. (Sincerity can affect ideas: we agree with that. I can be sincere in expressing my convictions). ${ }^{2}$ 203.

${ }^{1}$ J. V. Foix, "Poesia i Revolució", Quaderns de Poesia, 1 (1935), 4 and

2 J. V. Foix, "Algunes consideracions sobre la literatura i l'art actuals", L'Amic de les Arts, 20 (1927), 104. Some of these essays were published before in Revista de Poesia, 1-2 (1925), 65-70, and some others are new (among them, the one that I am referring to). 
And he adds:

When I write my prose - which I am loathe to admit I do, in the majority of cases, as the Super-realists do, in that I try to affix to it images of living reality - I conduct myself towards myself and my reader with sincerity. I am, then, sincere in expressing without fraud proven situations. And from the strictly literary point of view, I dare to affirm that I am right. I am, on the other hand, convinced that, in the world of ideas, this realism and this verity are not a universal reality. Or, in other terms, that they are neither the notion of Reality, nor the notion of Truth.

Now, in the philosophical, or perhaps even better, the metaphysical sphere, we could, by extension see it in other terms":

If the notion of Reality results in Perfection; if, according to Spinoza, Reality $=$ Perfection; if the reality which we attribute to a poem or to a painting depends, within literary history, on its being more or less real, and if, as other philosophers wish, Perfection is not humanly attainable, the notion of Reality becomes for us Super-reality before which we always find ourselves deficient.

And, so, he affirms convincingly:

No one can deny that I consider my prose works as realistic, thereby justifying the legitimacy of a label applied by those who with great pleasure cultivate infra-realism or a false copy of reality, of a human notion of reality, to which a great number respond with closed eyes and paralysed hearts.

\author{
THE POETRY: \\ A CRY OF ONE "DEFEATED "
}

As a matter of fact, reality is "sad and moving", that is to say, full of tensions, of self-divisions, and of confusions. And, 
so, the poet has to discover, through his disorder, "the true reality", "the veritable", which gives feeling to the one of each day and which, in short, is "anti-historical", and therefore, Absolute. Therefore, Platonically, or Plotinianly, "the poet, by means of the cavern listens to the mysterious world of echoes, and renews them". ${ }^{3}$ And, thus, "a similar tone, one of longing, is transmitted, thanks to poets, through the square of time". It is here that the Foixian poems are the fruit of a dramatic struggle. A struggle between the feelings and Reason or, to say it another way, between the disintegration of the personality and the desire of affirming it, between the reality of each day and the Absolute, that is to say, Reality, One and Eternal. ${ }^{4}$ And from here, in general, follows, in spite of some moments of communication, I was going to say, mystically, "a cry of one defeated, a phenomenon of spiritual dissociation similar to what the men of science indicate as a consequence of the death of an organism, with its self-divisions, total dispersion, and even, destruction." A claim, which is divided into three groups:

1. the "writings that best represent the 'retrogression' (refoulement) of that initial ambition", that is to say, the promise that "my hand will never sign my name, which would be inexorable in the realization of the personality which I aspired to

3 "Poesia i Revolució", 198-199.

4 The sonnets of Sol, $i$ de dol are a good example of this struggle and, especially, the sonnets 10,17 and 57 .

5 For example, in the sonnet "La Nit, diem, i el cor comú batega" (Sol, $i$ de dol, 42) and also "Dèiem: lá Nit! en una nit oberta" ( $O n$ be deixat les clans..., Barcelona, 1953, 131).

6 J. V. Foix, "Algunes reflexions sobre la pròpia literatura", L'Amic de les Arts, 31 (1929), 12. These reflections reappeared in KRTU, 12-23. 
project, dematerialized, like a brief shadow which skimmed over the sea perceptible for just a moment by fish, or across the smooth sky of autumn glimpsed for only an instant by a flight of birds." In this group "the uncertain, doubtful images which play in the poem, resolved within certain very strict norms, are a precise reflex of a violent inclination for all forms of imperialism, moral and physical." Now, "in their realization, the classic phenomenon of intellectual liberation for the work of art, is produced the other way around: each new poem is a new element of intoxication which imperiously claims other poems." And he adds, "It is a closed world that retains me by its unreal exoticness, and of which I remain, for a long time, prisoner."

2. "the poems which, according to the suggestion of certain literary schools, have allowed me an effective liberation in arbitrarily disposing of those same images with the objective of confusing their situation within the reality in which they move or transform themselves." Now, "In controlling them it has been necessary for me to avoid a double peril: the introduction of myself into the mysterious dead-end streets, which symbolise all my disintegrated ethics, and the discovery of the trick which makes its possessors so famous, to mass produce and with wit."

3. "a collection of attempts, made in the light of day, with strong optimism, and with a love of risk which it pleases me to consider with great literary sportiveness, uselessly generous if you wish, as I do not aspire to participate in any competition, and in fact refuse the championship. Some of these attempts I consider of a documentary value that brooks no discussion."

7 Ibid., 12. 
Moreover, Foix also carried the search into the field of literature and language. And carried it, that is to say, in total terms. In effect, for him, situated philosophically beyond the notion of time, literary schools are no more than "genres". And, therefore, are in some manner, interchangeable:

I cannot keep quiet when, in poetry, I love all trends. Perhaps because of an inclination that I have had for a long time, to consider literary schools not as such, but as genres. Say, for example, in the attempts of literary cubism, we remember the calligraphic attempts, they were not - they are not for me fleeting attempts, local in time and transitory, but a poetic fashion as valid as that which justifies the sonnet. I am going to say that a way of looking at the "historical" faces me with the facts - poetic and visual (or political and social) - in a way in which the dynamism of each hour is not a sudden attack, nor an excess but a normal periodical wave in the rhythm of a similar ondulatory line. A poet can face his own interior exoticness, his hearty emotionality, his aggressive lyric impulse - in the presence of a countryside, a beautiful lady, a social spectacle or a geological cataclysm in as many diverse positions of rhetorical objectivity as his own need requires. That is, that one can resolve literarily the conflict posed between himself and his ego or between himself and the exterior through every means, because everything, if the poet is skilful in his ordering, is, according to my understanding, and who can deny it being sincere, lawful. ${ }^{8}$

And he adds:

A poet can, without being hated by anyone, transcribe or describe in classic, in academic, in naturalistic, in "cubist", etc., terms according to his own conviction $\longrightarrow$ or his own taste- the abyss itself, or the playful stream, or Emília. What is demanded of the poet is that he be a master of ingenu-

${ }^{8}$ J. V. Foix: "... en versos ben tallats i arrodonida estrofa" (... in very well rounded verses and strophe), Quaderns de Poesia, 6 (1936). 
ity. (I do not conclude by saying "master in..."). And it the trends were to be accepted as rhetorical genres, one could pride oneself on alternating a game of hendecasyllables with an expressionistic acrostic. That is to say, the same Emilia could "pose" before the rhetorical objective and be "taken" by the poet with the same mobile diversity of process employed by modern photographers.

Thus, the search is carried out in the field of traditional poetics, and more concretely, in that of the medieval: the troubadours, Petrarch, Ausias March... Poetics which, in Italy, produced a/the Renaissance and which, in Catalan territories, resulted in an abrupt decline in the language and literature. From the beginning of the century, all attempts were made to recover from this decline in order to revitalize the entire history, which had seemed possible at one time. ${ }^{9}$ In addition, Foix carried the

9 Pompeu Fabra, for example, in his great systematization of the language, did not intend "the resurrection of the medieval language, but to form the modern language as it would be without long centuries of literary decadence and the oppression by a foreign language" (El català literari, Barcelona, 1932, 75). In the strict field of the literary creation, Ors, was - if I am not wrong - the first in expressing this idea ("Vers l'humanisme", in Glossari 1906, Barcelona, 1907, 262-264). And, after him, Carles Riba, among others, developed the same idea (Escolis $i$ altres articles, Barcelona, 1921, 72-76 and 145-148; see also the poetical world of the Estances, Barcelona, 1919, and the interpretation of Joaquim Folguera, Les noves valors de la poesia catalana, Barcelona, 1919, 91-92). On the other hand, Foix, in his article mentioned in the note 10, says: "Josep Carner, like Ronsard in France, Tasso in Italy and Garcilaso de la Vega in Spain, gave the maximum perfection to the poetical expression maintaining the classic element in a epoch little favorable because of the lack of immediate predecessors ... Carner, on his own, has carried out, partially, everything that, in our opinion, the 'Renaixença', for which we are struggling, had to carry out". And he adds: "Many of the points which were indicated in the French Plèiade ... have been carried out spontaniously by our poet. Gracious and subtle, his poetry is, in many respects, a doctrinal manifesto". 
search into the field of modern poetics: those of Avantguardism. For Foix, undoubtedly, the use of Avantguardism supposed, for the culture of the country, a host of perils. In 1921, in an essay which appeared in the journal Monitor, $\mathrm{n}^{\circ} 1$, he indicated "the four elements" which are "the principal factors disturbing the rapid elevation of our language and our literature to their original dignity": denial of racial origins, Avantguardism, Floridity and Demagogy. In the beginning "the natural tendency" to seek foreign models "is defensible". Now:

what we believe prejudicial is the immediate version in Catalan of this youthful activity, quite often intoxicated, over which neither judicious control nor a severe critique has been exercised. Further: the spasms stimulated by the frequency of these readings, have given a series of works foreign to our national essence and driven away realistic feeling and the characteristic expression of occidental culture. ${ }^{10}$

And, in another essay, which appeared in $\mathrm{n}^{\circ} 2$, he indicates some traits of modern literature, and more concretely, of Avantguardism - "yearning for Renaissance", "fever of research", "arrival", exaltation of "ignorance" and of "facility" which, adapted without a minimum of criticism, could bring Catalan Letters nearer to a cataclysm:

The direct results are now insignificant and inaudible; but not so the derivations which, lacking a control and tending directly to the mutilation of the language in the moment of its rehabilitation, could exercise a dangerous influence.

"Should we bring", he asks, "our retreat to a point that denies us all modern reading for our own good health?"

${ }^{10} \mathrm{~J}$. V. Foix, "Algunes consideracions preliminars", Monitor, I, 1 (1922), 2. 
All in all, Foix, from the first moment, worked with decision with the proposals of Avantguardism, above all, as a theoretician and critic. In effect, Foix, who tended more to poetic creation or journalistic information ${ }^{11}$ than to critical theory, published some essays of positive importance. Thus, in 1925, he submitted to the Revista de Poesia an essay which, inspired by Dadaistic sources, completed the futuristic stage and opened a new one: the Surrealist. A termination and a proposal which, to a certain extent, confused some of our modern critics! Thus, like Tzara, he denied Apollinaire's condition as Avantguardist, and in a correlative manner, affirmed that "although he has been among the Dadaists which have emerged as their own Avantguard". In fact, "Dadaism was a training for irresponsibility. Here are its most useful athletes: its superrealists". "Their originality could be this: the great adventure of self-liberation from all motors or propellers, to navigate through the excessively vast sky of the imagination, without direction and with the prescience of emerging without injury." These ideas, Foix applied to Catalan letters. And, therefore, he gave a completely negative and, I would say, also logical image:

Diverse manifestations often opposed to the group called "Avantguardist" have really never been quite clarified in Catalonia. Futurism, Dynamism, Cubism, Dadaism, Super-realism, etc., are expressions current in our conversations. All in all, I have observed quite recently, how difficult it is for

${ }^{11}$ Foix gave much and punctual information about the Avantguard movements in different periodicals: Trossos, La Revista, L'Amic de les Arts, etc., but, especially, in the literary page of the newspaper La Publicitat, which he wrote for many years. 
someone to distinguish them clearly. This difficulty of classification is a sign of little maturity in the hurry to introduce certain daring innovations. Thus, just as a number of our pretended poets are incapable of correctly composing a letter, a number of Avantguardists are found in an identical position. He who constructs a sonnet and does not know how to write a postcard is one from whom, if we note him well, the sonnet is even worse than the few badly written lines. He who writes verses without punctuation, or free words, or has the luck to compose a literary puzzle has to know how to write a sonnet correctly. The daring, the innovations, can only be permitted to exceptional temperaments. Some pastiches of Avantguard literature that have appeared in Catalan make you hang your head in shame.

In the desolation of this panorama Junoy was the unique exception though in the visual arts: "Junoy has achieved the realization of some of his remarkable compositions through procedures in which literature has not intervened". SalvatPapasseit "not only failed in his intention to introduce new forms, but demonstrated no understanding of their elementary significance". And, finally, Folguera "perhaps" was "the only one of our generation that understood the extent of the literary renewal".

On the other hand, Foix, collaborator of the Surrealists and obsessed by civic considerations, proposed, in 1930, the political compromise of the artist. And published, in $\mathrm{n}^{\circ} 1$ of Quaderns de Poesia some disquisitions on "Poetry and revolution", in which he rigorously defined a position which he has faithfully kept to all his life:

The poet, as a poet, must have no other lyrical motivation than that proper to poetry. The only thing that counts for him is the revolution provoked by the process of adaptation of the lyrical impulse to his epoch, which exalts the latter, which illuminates it. A political or social revolution gives the poet unexpected elements for his escape. The poet finds again through the medium of new symbols that which is eternal. 
The poet, as a poet, has his revolutionary obligations. His revolution however is indifferent to the revolution of the majority. When this happens, the poet is quiet. If he wants to intervene as such, the poetry is drowned in morbid pools of rhetoric. But rhetoric is as adverse to poetry! As it is by chance, to a literary competition.

The poet is opposed to his epoch. He searches among the runes or the monuments of each civilization for the elements of mystery. In every epoch, under the most contrary of regimes, he holds vigils for mystery, for its permanence. He cultivates magic and makes Chinese shadows on the wall of eternity with the material elements endowed by the sad and mobile "reality". He searches for the veritable reality, the "other reality". ${ }^{12}$

\author{
A PARADIGMATIC POET: \\ FROM FUTURISM TOSURREALISM
}

In the second place, in the field of poetic practice, Foix, well informed and a good investigator, translated poems of some of his French and Italian colleagues and tried to adapt some of their works, and, thus, became a kind of paradigmatic synthesis of the entire Avantguard, or, at least, of some of its most significant proposals. In effect, Foix, at twenty, was already participating in the discovery and diffusion of Futurism. And until, at the precise moment, everybody even identified him with the model of "futuristic man". Salvat, for example, enclosed him in the "Lletra d'Itàlia" (Letter from Italy) emphasizing his complexity at bottom: "Here in Rome it is whispered that in order to understand Foix of Sarrià, everybody must read Sophocles first. Laieta has cried, because she will have to begin again with Narro... because she does not know

12 See also the review that he devoted to the Position politique du Surréalisme, by Breton, in Quaderns de Poesia, 5 (1935), 31. 
how to read." And Folguera, in the letters addressed to the poet López-Picó, said with irony: "We never insist enough with a Futurist, fresh, lover of calves and with a stomach problem. Foix, books, etc." 13 Of Futurism, Foix, who rendered Luciano Folgore into Catalan verse, introduced some aspects of his nationalist radicalism. And, above all, the passion for the myths of youth, of the machine, of sport, of risk... A passion articulated in two of the six parts of Sol, $i$ de dol: the IV and the V.

Cal risc en terra i mar, i en l'art novella,

Per a besar un cos xop sota canella

I caure als trenta-tres, com Alexandre!

(Risk is necessary on land and sea, and in art nouveau, in order to kiss a drenched body under a canopy and fall at thirty-three, like Alexander!)

And, moreover, he described the reality of each day through a series of more or less unconnected impressions, composed some free words, in a sporadic manner, and even a calligram:

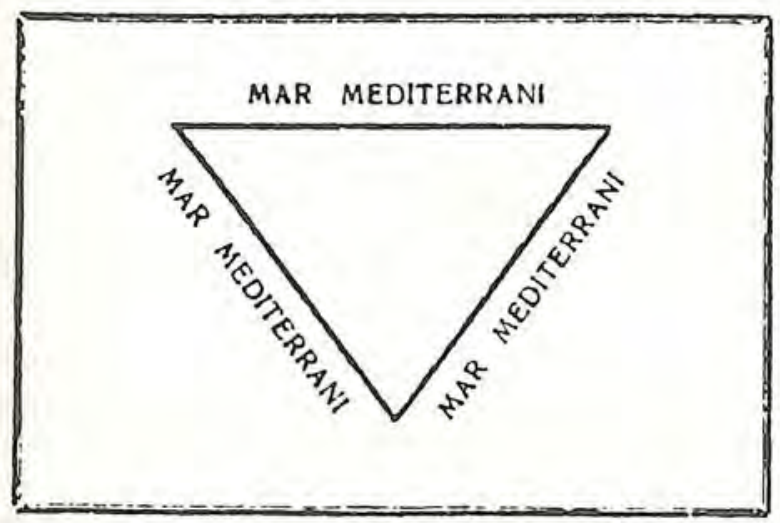

${ }^{13}$ J. M. López-Picó, "Notes per a la biografia de Joaquim Folguera", in A mig aire del temps, Barcelona, 1933, 33 and also 27. 
Moreover, Foix was the first, and almost the only one that treated Dadaism, and more concretely the group that surrounded the magazine Litterrature, with a minimum of respect. Thus he cultivated a theory of poetry which coincided with Dada: "A sign of the times (our poets' revolution), is its interpretation as an activity of the spirit". ${ }^{14}$ In 1918 , he translated Tzara and Soupault. And at the same time, he initiated a type of prose narrative which, through a conjunction of associations, of substitutions and/or of transformations, intended to reproduce the fluency of a dream. A conjunction that mixed the easily identifiable names and situations of daily reality with others that were fantastic. And which, now and then, uncovered the elements that composed it:

This memory, turning into cruel jealousy, makes me see Gertrudi as a tedious movement, realizing WITH EMPHASIS that it was no more than a bunch of perfumed rags.

I pushed her into the abyss: twisted with fright, I heard the lament of the dying like the last spasm of a worn out gramophone record. ${ }^{15}$

And, like some Dadaists, he participated, from 1924, in the adventure of Surrealism. Now, Foix, having been, in general, a kind of paradigmatic model of the sect, having translated some of its most illustrious leaders such as Breton and Éluard,

14 "Poesia i Revolució", 199. According to Foix, "after some experiments, still artistic, Dada pretends to affirm: to the poetry as a means of expression, it opposes the poetry as a spiritual activity. Above art and good taste. Above literature" ("Dada", in D'aci d'allà, XXII: 179 - 1934).

15 J. V. Foix, "Gertrudis", Trossos, 5 (1918), 4. See also "Singular narració", Trossos, 4 (1918), 6. Foix published again both pieces of prose with light changes, the second one under the title "Plaça Catalunya-Pedralbes", in Gertrudis, Barcelona, 1927, 39. 
and having contributed to the diffusion of the paintings of Miró and Dalí, did not make any concrete or paradigmatic proposal nor did he participate in any of its acts of public affirmation or provocation. In $\mathrm{n}^{\circ} 31$ of L'Amic de les Arts, for example, he established a clear distance between himself and Dalî's group, and his collaboration was limited to some poetic prose and to an essay. An essay which, in spite of picking up some Surrealist anxieties, constitutes a personal confession: an authentic self-criticism. In general, Foix, stimulated by the group, intensified his researches into the world of dreams, freeing his imagination, adapted some of his most scholastic symbols, and in the end, made some trials of automatic writing. In effect, the fragments from Diari 1918, published in Gertrudis, in KRTU ${ }^{16}$ and in the magazine Helix, are prose of a prodigious lyrical and verbal concentration, truly "incisive visions", as Gimferrer says, which transform the daily reality of Sarrià, or of el Port de la Selva, into a universe of fiction, full of strange associations and substitutions and, in the long run, of violent transformations. A universe, which, through symbols, and objects, taken at the same time from the metaphysical painting of Giorgio de Chirico - towers, castles, gloves, mannequins, etc. - and from Surrealist poetry - horses, shoes, umbrellas, tubes, closed streets or very high walls, etc. transfers the weakness of the poet into the context of a hostile brutal humanity. ${ }^{17} \mathrm{~A}$ humannity which identifies him with a diminished being: "I am hunchbacked and, by day, the people on the streets laugh when I pass and say that I am mad". ${ }^{18}$ Moreover, he gave the press fanciful telegrams and news relea-

16 P. Gimferrer, La poesia de J. V. Foix, Barcelona, 1974, 39.

${ }^{17}$ Gimferrer, ibid., 12-17.

${ }^{18} \mathrm{~J}$. V. Foix, "On aniré tot sol", in KRTU, 52. See also Gimferrer, ibid., 34-36, where he explains this text in relationship to the sonnet "Fu- 
ses, ${ }^{19}$ and in this dispersed manner ended up publishing some of his poems. Some poems, with which in a climate of desolation he tried automatic writing or, if not more, the disordered fluency of the dream: free verse, chaotic enumeration, suppression of punctuation signs, audacity in the metaphorical creations, etc. Sometimes, these essays seem pure, that is to say, mechanical:

Malles del somni, negrors pisciformes, estels colgats dels hams sagnosos: Destralegeu amb mi, quimeres blaves, escampem gavarrots pels asfalts verticals!

Els globus que pengen del cel són de pell fina, inflada de venes vitals. I he dibuixat damunt el meu pit nu les hores mortes!

(Nightmare, black fish-forms, stars hung from bloody hooks;

Use me as a hatchet, blue chimeras, we scatter tacks on vertical roads!

The balloons which hang from the sky have fine skin, inflated with vital veins

And I draw on my naked breast the dead hours!)

Others seem to express a depth of rationality well articulated. A depth which, for example, acquires quasi-prophetic tones:

Reculeu, voluntats ordenades entre ploms estrafets i betums en deliri!

Cediu, coratges excitats per les llanes i els fums esperitosos!

Lliureu-vos, guerrers insepults: Som ací els herois nous.

Nascuts en plàcides marees,

giré carrer enllà, o-i! ..." in Sol, i de dol, 77. It must be said that both texts, under the titles "Cotillaire, cotillaire..." and "Escenes de platja", appeared for the first time, shortly spaced, in L'Amic de les Arts, 30 (1928), 236, and 25 (1928), 192.

19 See one example of these texts in J. V. Foix, Allò que no diu "La Vanguardia", Barcelona, 1970. 
Els nostres braços són rius vagabunds eixits de güells tenebrosos;

Portem la lluna al front i el nostre cos és la palmera ombriva.

(Recoil, wishes arranged between counterfeit lead and bitumen in delirium! Cede, courage excited by wool and volatile fumes!

Free yourselves, unburied warriors: We are here the new heroes.

Born in quiet tides,

Our arms are vagabond rivers flowing out of dark squeals;

We carry the moon on our forehead and in our bodies is the shady palm.)

\section{Or he recalls the dramatic solitude of the man:}

Sóc sol entre cent mil, cadascun de vosaltes és sol entre tots;

La meva boca clou la vostra, el vostre braç atura els meus.

Les portes seculars són closes per sempre com els cors ofegats per les molses de les vesprades pirinenques.

(I am alone among a hundred thousand, everyone of us is alone among others;

My mouth closes yours, your arm stops mine.

The secular doors are closed for always like the hearts smothered by the moss of Pyreneean evenings.)

Now, Foix, after the politizing of Surrealism and the dissolution of Dalís group, started, without betraying any of his principles, ${ }^{20}$ a new venture. A new far-reaching venture that

20 After the civil war, for example, he collaborated with Club 49 and the periodical Dau al set and he published some very significant articles: "El joc etern", Poesia, 4 (1944-1945), 4; "Els poemes de Max Jacob, tan clars...", Ariel, I: 1 (1946), 16. See also the Poemes inèdits, which can be found in Obres poètiques, Barcelona, 1964. 
consisted in the reevaluation of his attitudes, and above all, in a process of purification of his use of language and an intensification of philosophic and moral aspects. He collaborated with the people of ADLAN ("Amics De L'Art Nou", Friends of the New Art) and, at the same time, with Riba and his group. And from 1947 on, he produced his great books of poetry in which he mixed the new attempts with the old and submitted all to profound revision.

JOAQUIM MOLAS UNIVERSITAT DE BARCELONA

Translated by Louis J. Rodrigues

This article appeared before in Catalan (J. Molas, La literatura catalana d'avantguarda (1916-1938), Barcelona, A. Bosch, ed., 1983, 54-63). 